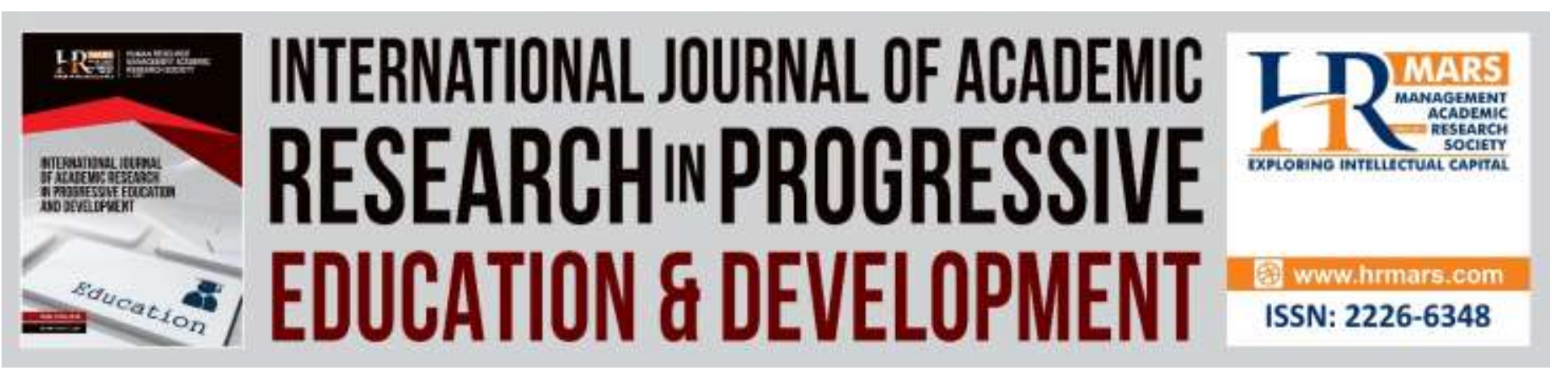

\title{
Effectiveness of Using Advertisement in Improving Writing Skills among the Islamic Senior Higher School's Students
}

\section{Razali Mahmud}

To Link this Article: http://dx.doi.org/10.6007/IJARPED/v8-i2/6109

DOI: 10.6007/IJARPED/v8-i2/6109

Received: 19 Jan 2019, Revised: 27 Feb 2019, Accepted: 10 March 2019

Published Online: 29 March 2019

In-Text Citation: (Mahmud, 2019)

To Cite this Article: Mahmud, R. (2019). Effectiveness of Using Advertisement in Improving Writing Skills among the Islamic Senior Higher School's Students. International Journal of Acdemic Research in Progressive Education and Development, 8(2), 405-417.

\section{Copyright: (C) 2019 The Author(s)}

Published by Human Resource Management Academic Research Society (www.hrmars.com)

This article is published under the Creative Commons Attribution (CC BY 4.0) license. Anyone may reproduce, distribute, translate and create derivative works of this article (for both commercial and non-commercial purposes), subject to full attribution to the original publication and authors. The full terms of this license may be seen at: http://creativecommons.org/licences/by/4.0/legalcode

Vol. 8(2) 2019, Pg. 405 - 417

Full Terms \& Conditions of access and use can be found at http://hrmars.com/index.php/pages/detail/publication-ethics 


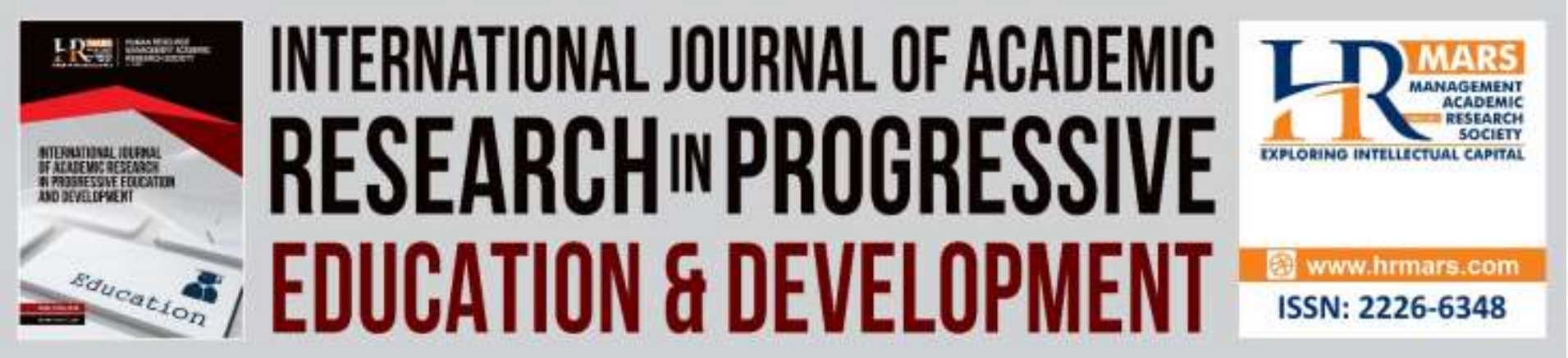

\title{
Effectiveness of Using Advertisement in Improving Writing Skills among the Islamic Senior Higher School's Students
}

\author{
Razali Mahmud \\ Department of Tadris Bahasa Inggris, Faculty of Tarbiyah and Teacher Training, Institut Agama \\ Islam Negeri (IAIN) Langsa, Aceh, Indonesia \\ Email: razalimahmud328@gmail.com
}

\begin{abstract}
This study analyzes the effectiveness of using advertisement in improving the writing skills of students at the Islamic State Senior High School, Madrasah Aliyah Negeri (MAN) 1 Langsa, Aceh Province, Indonesia. To gather the data, the interviews are conducted with selected lecturers and students and then qualitatively analyzed. The analysis was conducted through three steps; data reduction, data display, and conclusion. The study found that the students were glad, enthusiastic, and motivated in writing lessons by using advertisement. The use of advertisement in teaching has improved students' ability in writing skills. However, some students faced difficulties in expressing their ideas in writing lessons due to the lack of vocabulary. Based on these findings, it is suggested that all teachers should use advertisement intensively in their teachings to further enhance the writing skills of their students.
\end{abstract}

Keywords: Advertisement, English Teaching, Writing Skills, Islamic Senior High School.

\section{Introduction}

Writing is the most complex skills in language learning as there are many writing-related aspects that students must be aware of (Babayigit and Stainthorp, 2010). Having advanced vocabulary is a must in writing lessons; otherwise, it is completely difficult to express ideas in writing. Many high school students find it difficult to write in English as a foreign language. Having inadequate vocabulary and ignorance of several important components in writing are the main factors that make students difficult to write well in English. These writing aspects include vocabulary, grammar, punctuation, spelling, sentence structure, and coherency of sentences. On the other hand, teachers also have to explain about genre before asking students to write, including the types of text teachers ask students to write. There are several text types that students need to know, for example, recounts, narratives, descriptive, reports, procedures, and arguments. In addition, the media of teaching is also one of the important components influences the success of teachers in improving the writing skills of students (Hapsari, 2007). 
In essence, the media of teaching are completely needed in the teaching and learning process (Archer et al. 2014). Therefore, all of the teachers are required to use all media that can be provided by the teachers themselves or the schools. At least, teachers can use cheap and efficient media available in the schools as the media of teaching (Arsyad, 1996). Some interactive and innovative media should be introduced by in their teaching and learning process.

In the era of information and communication technology, media of teaching are absolutely needed in the teaching and learning process, especially in writing subjects. Heaton (1995) states that writing is complex and difficult to teach and also to learn, it requires mastery not only of grammatical and rhetorical aspects, but it also needs a proper conceptual and judgmental elements. Students' difficulties can be found when students write an English text, most of them make mistakes in their writing. The students find difficulties in writing as they do not have enough writing skill and do not rely on the correct rules of writing.

Thus, to write well in English, a student must learn and understand writing skills (Peni, 2006). However, most of the students find that writing is one of the difficult skills in learning English. It is obvious that there are some English teachers experience difficulties to solve this problem on how to use appropriate techniques in teaching English writing (Munir, 2016). This case can be seen from the way English teachers teach writing during the process of teaching and learning. It is influenced by the way the teachers teach, for example, the teachers do not teach all the rules of writing and the students are not provided by sufficient writing exercises. Therefore, the writing skills of the students are failed to improve in the schools.

Furthermore, to succeed in writing well, the students have to learn how to write correctly, they must write based on the rules; therefore, they must know and understand the correct rules of writing. To assist the students to understand those rules, the teachers have to teach writing by using appropriate method and techniques such as media of advertisement, pictures, and videos. Previous studies documented that the use of media in teaching and learning process has improved student abilities and achievements (Trier, 2006; Liu, 2010; Suh, et al. 2010; Al-Hammadi, 2011; Cho, 2012; Ismaili, 2013; Keshta and Harb, 2013; Munir, 2016; and Xodabande, 2017).

Unlike previous studies that mostly investigated the effectiveness of media in teaching English writing, this study focuses its analysis on English writing as a foreign language. Additionally, most of the previous studies explored the effectiveness of teaching media of video, movies, network telegram, games; this study focuses its analysis of the use of advertisement media in improving writing skills of the students of Islamic senior high school in Aceh Province, Indonesia. The use of advertisements as teaching media in English writing classes among students of the Islamic senior high schools have been rarely investigated, thus this study intends to fill this gap, taking the case of the Islamic State Senior High School of Madrasah Aliyah Negeri (MAN) 1, Langsa, Aceh, Indonesia.

The findings of this study are hoped to provide evidence on the effectiveness of using advertisement media in improving English writing skills. It is also hoped to shed some lights on the way of English teacher to use advertisement as an effective media to enhance students' writing skills.

The rest of the study is structured as follows. Section 2 reviews selected relevant literature, followed by the research method in Section 3. Section 4 presents the findings and their discussion. Section 5, finally, concludes the paper. 
INTERNATIONAL JOURNAL OF ACADEMIC RESEARCH IN PROGRESSIVE EDUCATION AND DEVELOPMENT

Vol. 8, No. 2, 2019, E-ISSN: 2226-6348 @ 2019 HRMARS

\section{Literature Review}

Writing is a representation of language which needs a process. Harmer (2004: 86) states that writing is as a process that is often heavily influenced by the constraints of genres and then these elements have to be present in learning activities. In addition, Kroll (2003) categorizes writing as one of the intellectual activities that require a higher level of thoughts. To create good writing, someone needs to demonstrate mastery over contextually appropriate formats for the rhetorical presentation of ideas as well as mastery in all areas of language.

To produce good writing, it must convey five general aspects (Babayiğit and Stainthorp 2010; and Hyland and Hyland 2019). These aspects include: (a) content, it is concerned with relevance, clarity, originality, logic and act; (b) organization, is concerned with the way of how the writer arranges and organizes their idea and message in writing from which consist of some partial order; (c) language use, it deals with the rules of verbs, agreement, articles and act; (d) Vocabulary, a good writer should master vocabulary and idiom as the language aspect dealing with the process of writing; and (e) mechanic, it deals with capitalization, punctuation, spelling, etc.

\section{Purposes of Writing}

According to Hartig (1962), there were at least seven purposes of writing, namely: assignment, altruistic, persuasive, informational, self-expressive, creative, and problem-solving purposes. First, writing is done for the purpose of completing the instruction or assignment. In this case, the students write a text because they have an assignment. Students do not write because they want to write. For example, the students write a persuasive text because their teacher asks them to make a persuasive text.

Second, writing is done for the altruistic purpose that is to entertain the readers. A light-hearted approach to dull or difficult material could help your reader to absorb it. Satire lets you expose the shortcomings of individuals, ideas, and instructions by poking fun at them. An intention to entertain can add savor to many kinds of written messages, such as short story, novel, comic, etc.

Third, writing is done for the persuasive purpose is to persuade the readers about the truth of ideas on the text. Students probably have strong views on many issues, and their feelings may sometimes support them to explain to the readers. When they write, they can persuade readers to be interested in our ideas. For example, if they have written about "Do Not Step on the Grass". In this writing, they invite people's interest not to step on the grass since it will damage the beauty of the park. This type of writing purpose is related to the use of advertisement in teaching writing since one of the functions of advertisement is to persuade people to use or to purchase the things being advertised. Therefore, using advertisement in teaching writing is obviously essential to assist the students in improving their ability in writing a persuasive text. Muslich (2008: 4) defines a persuasive text as the text aim to persuade the readers to do something. In this case, the writer expects readers' motoric attitude in action form based on the writer expectation in his writing.

To persuade reader, a verbal art is also can be used to persuade someone to do something which is intended by the speaker or writer at the time or future is persuasive text, such as speech, advertisement, etc (Keraf 2007: 118). The persuasive text does not consist of intimidation or other kinds of harnesses toward the readers to absorb our idea. Therefore, the writer must do certain effort to invite the reader, such as showing some evidence of his writing. In short, persuasive text language is different from other texts, such as journal, news, etc. The persuasive text uses certain 
language is chosen by the writer according to writing persuasive text purpose. Persuasive language must be able to persuade and entertain the reader toward the invitation of the writer in the text. In writing persuasive text, the writer must convince the readers' belief as it as the main element of persuasive text.

Fourth, writing is done for an informational purpose. According to Siahaan (2008), writing is the skill of the writer to communicate information to a reader or group of readers. Her or his skill is also shown by the ability to apply rules of the language in writing to transfer the information to the readers effectively. Presenting information is one of the most common writing purposes. Some professional writers carve careers out of writing articles and books that fill gaps in the public's knowledge. These writers investigate a timely topic, become short term experts, and pass along their finding in an easily understood form. The information you provide shows them how well you mastered the course material.

Fifth, writing is done for a self-expressive purpose. In this purpose, writing is a way to introduce ourselves to the reader. Creative writing includes personal texts, fiction, plays, and poetry, as well as journals and diaries. But self-expression has a place in other kinds of writing too. Almost everything people write, provide the opportunity to display their personality and mastery of words and to enliven their prose with vivid images and fresh turns of phrase. Sixth, writing is done for creative purpose. In this purpose, writing is as a way to improve the artistic value of a text. The writer can write all of his feel and imagination through written text. Even though the meaning of sentence different from the real meaning, Nevertheless, that is one of the artistic values of a text, a reader needs a good translation to translate sentences by sentences of the text. The examples of this purpose are a poem, prose, lyric of a song, etc.

Finally, the purpose of writing is for problem-solving. When people write texts, not all of his arguments can be absorbed by the readers. The problem-solving purpose is a writing purpose to explain, solve, browse and research about the people thinking, argument and idea before they publish their writing in order to be understood by the readers such as a critic on newspaper or magazine.

\section{Teaching Writing Technique}

Suyanto (2008: 69) divides technique of teaching into four stages, namely: copying, guided writing, substituting and free writing. The four techniques of writing need to be adjusted to the level of the class and the students' development of the English language. The first step of writing technique is copying. It is writing activities performed for the lower classes, especially for children who are just learning English. They are able to pronounce the words, but still difficult to write the words because the English spelling is different from Indonesian spelling. Therefore, this is the correct technique. For the early stage, the teacher can ask the students to copy the word or phrase that is provided directly. In this activity, the teacher together with the students pronounces the word, phrase or short sentence together and then they students copy the word. In the second step, the guided writing technique is done by using a text or a short dialogue with a few words omitted. Students are required to complete the text or a short dialogue with the omitted portions. This activity is also called by fill-in exercise.

The third step of writing technique is called substituting. This technique can be a matter of rewriting a sentence or a text, but there are some parts that are replaced with the word that has 
the same meaning. Through this technique, students' vocabulary will be increased. Finally, the last writing technique is free writing. It is a free writing activity that needs much vocabulary and master in grammar. In this technique, a student has a chance to apply their knowledge that they have gotten in writing form. Even though this is free writing, a teacher must give instruction based on students' ability in writing English text.

\section{Media of Teaching}

Suyanto (2008: 68) asserts that English learning becomes more interesting and effective if the teacher uses interesting media of teaching to improve students' motivation since students like all of the visual things. The use of concrete things as media of teaching makes the teaching process to become more interesting. Media can improve students' motivation, give simulation, bring psychological effects for students, create an interesting atmosphere in teaching and explain material effectively.

The word "media" is derived from "medius", which literally means in middle, intermediate or introduction (Arsyad 1996). In Arabic, the media is an intermediate or an introductory message from the sender to the receiver of the message. If the media is understood as material or events that establish conditions that enable the students to acquire the knowledge, skills or attitudes. In this case, the teacher, books and school environment are media. More specifically, the notion of media in the learning process tends to be interpreted as graphics media, photographic or electronic images, process, and reconstruct visual or verbal information.

Teaching media includes printing media (such as book, magazine, brochure, study guide, journal, etc), exhibition media (such as poster, graphic, painting/frame, model, idol, etc), projected media (such as OHP, sound slide, film strip); Audio record media (such as foreign conversation, etc.), Video and VCD; and computer (Kemp and Dayton 1985).

\section{Advertisement Media}

According to Lee and Johnson (2013), advertisement is derived from the Latin language "adverte", which literally means instructing. Advertisement can be defined as a commercial and non-personal communication about an organization and its products transmitted to a target audience through mass media such as television, radio, newspapers, magazines, direct mail, outdoor billboards or public transportation.

Furthermore, Jefkins (2016) asserts that advertisement is messages that offer a product that is addressed to the public through a medium. However, to distinguish it from the usual announcements, advertising is geared to get people to buy. The advertisement has several functions; it can convey messages which are wanted to be conveyed by the producer to the society. The advertisement campaign is one of the best known and most widely discussed of people, this is because its range is wide. The advertising campaign is also a very important instrument, especially for companies that produce goods or services that are directed to the general public.

Looking at its types, Widyatma (2009: 84) categorizes advertisement into four categories, namely: advertorial, display, running text, and product advertisements. Advertorial advertisement is written as news that accommodates self-willingness, by giving informative writing to the readers such as in newspaper and magazine. Advertorial advertisement has a wider size than other kinds of advertisement. However, the technique of conveying a message is more focused on form. 
Display advertisement is an advertisement in the announcement. instruction, campaign, and so forth, while running text advertisement is kind of advertisement in the form of sentence consecution that consist of some moving characters follows the display, its displaying is accommodated by consumer's need. Finally, product advertisement is a kind of advertisement which is focused on the preview display of the product by showing the advantages of the product in order to show the brand image to the customer.

\section{Research Method}

This study addressed the following research questions: How is the effectiveness of using advertisement in teaching writing? and what are the difficulties faced by the teachers in teaching writing persuasive text by using advertisement?. To answer these research questions, this study intended to find out the effectiveness of using advertisement in teaching English writing session among the Islamic senior high school. Thus, this study observed the students' activity in writing persuasive texts based on the advertisement provided by the English teachers. In addition, the study also wanted to find out the difficulties faced by the English teachers in teaching writing persuasive text by using advertisement.

To answer the above-mentioned objectives, this study is based on the interpretivistic research paradigm. This research paradigm is the most widely adopted research paradigm in a qualitative research that believes human behavior is multifaceted and it cannot be determined by pre-specified probabilistic models. The interpretivists argue that what exists in the social world is what an individual thinks exists (Potrac et al., 2014). As this study interviews selected respondents and their responses are very much determined by situations and environmental factors of the respondents other than their genes. Thus, their behavioral responses are quite unlike a scientific variable which is uneasy to control and are affected by several factors that are mostly subjective in nature (Thanh and Thanh, 2015). Therefore, the interpretivistic research paradigm using in this study is believed to be the best qualitative research approach adopted in this study to describe teachers' and students' daily studying and learning activities in the schools rather than in the controlled environment. The uses of interpretivistic paradigm and qualitative approach in the study enables us to seek experiences, understandings and perceptions of teachers and students on the effectiveness of using advertisement in improving writing skills among the Islamic senior higher school's students.

The participants of this research were the students of Islamic senior high school of Madrasah Aliyah Negeri (MAN) 1 Langsa, Aceh, Indonesia. Two class of the second-grade students were selected consisted of 30 students each. Two English teachers were also selected as participants of this study. These English teachers were interviewed concerning their difficulties faced in teaching English writing persuasive text by using advertisement.

The data were collected through observations on the process of teaching and learning English writing persuasive text in the two classes. In this observation, the researcher observed if the English teachers used advertisement effectively in teaching writing a persuasive text. The study also used a semi-structured interview as an instrument. This interview aimed at gathering more data and information needed from the teachers on the use of advertisement in teaching writing persuasive text and the teachers' difficulties in using advertisement in teaching writing. In addition to two English teachers from each class, to further confirmed the findings from teachers' 
interviews, this study also interviewed 10 students, five students from each class, to gather further information on the effectiveness of the use advertisement media in teaching English writing among students. During the interview, 15 questions related to the focus of the study were asked. The questions and responses were conducted in the Indonesian language.

The findings from observation are then analyzed qualitatively. Data analysis is the process of systematically searching and arranging the interview transcript, field notes and other materials that are accumulated to increase our understanding of them and to enable us to present what we have discovered to others (Bogdan and Biklen 1998). Data analysis is a procedure of data collection, data display, and conclusion. Thus, it is a procedure in which data collection, data reduction, data display, and conclusion drawing take place interactively (Miles et al., 1994).

Specifically, in this study, the collected data were analyzed by the following procedures: data reduction, data presentation, and conclusion drawing. Firstly, the data were collected by interviewing two English teachers and observing teaching and learning activity in the classrooms. Then, data reduction was done by transcribing interviews about the use of advertisement in teaching writing persuasive text, teachers' difficulties in using the advertisement and the efforts made by the teachers to solve the problems. Finally, the data were interpreted to explain the phenomena studied in the field based on the research objective, clarifying, describing and draw some conclusions. Interpretation, clarification, and description were implemented to gain the final results in order to make it clear and understandable by various levels of readers.

\section{Findings and Discussion}

In this section, the findings from observations and interviews both with English teachers and student are reported and analyzed. This is done to find out how was the effectiveness of using advertisement in teaching English writing and what were the difficulties faced by the teachers in teaching English writing by using advertisement.

The first participant of this study was Teacher A, an English teacher at the school. To her perspective, using advertisement as a media in teaching writing was very effective. She stated that students had a good response when she used advertisement in teaching English writing and they were motivated to learn writing. They were very happy and enthusiastic in teaching and learning process. The influence toward students of teaching writing by using advertisement as a media was very good. It has increased students' ability in English writing and improved their vocabulary. However, she further added that some students faced difficulties in learning English writing by using advertisement. This is mainly due to lacking students' vocabulary and tenses that made them difficult to response during the teaching-learning process.

On other hands, other teacher participants, Teacher B that used both pictures and advertisement as teaching English writing media, asserted that "teaching English writing is easier by using the picture as media than using advertisement". According to her, by using pictures as the media, it made the students more interested to learn writing in English. They could discuss to describe people or view those pictures. She also said that pictures were easy to prepare, meanwhile, the advertisement was difficult and need a long time to prepare. 
In addition, Teacher $B$ said that the students did not find any difficulties when she used pictures as the media in teaching English writing, but the students faced difficulties when she used an advertisement in teaching writing. The teacher can prepare the pictures as teaching materials at home like calendar and so forth. But if he used an advertisement, he had to prepare the materials by searching on the website, newspapers, magazines, and so forth. It needed such a long time. To conclude, Teacher B stated that using pictures as the media was more effective than using advertisement in teaching English writing.

Furthermore, the findings from interviews with teachers were further confirmed by the interviews with ten students. Student A, said that his teacher has ever taught writing by using media. He said that his teacher ever used picture and advertisement as media. According to Student A, when the teacher used advertisement as media in teaching, he could respond and thinks well effectively. He felt the enthusiasm in writing and could improve their vocabulary. In addition, he said that he did not have difficulties when he learned and it made easily if the teacher used media in teaching writing.

Similarly, Student B said that the English teacher has ever used advertisement as a media in teaching writing. She confirmed that, if her English teacher used advertisement in teaching writing, she was an enthusiast during the teaching and learning process. According to her, when the teacher used advertisement as a media of teaching, she could easily improve her writing skills. Learning English writing with the aid of advertisement media, "I enjoy a very fun and interesting writing class", she said. Finally, she also confessed that she had difficulties in learning English writing due to her lacked vocabulary.

The other students, Student $C$ also stated that her teacher used pictures and advertisement as a media. The advertisement was an interesting media to learn English writing. The language in the advertisement made me enthusiast to learn. It was easier if my teacher taught English writing by using the media. She also said that advertisement was an effective media to improve my knowledge in English writing. In addition, she asserted that the difficulties she faced in English writing were mainly due to the limited vocabulary that made her difficult to write well in English. Student $C$ perception of the use of media in English writing session is further confirmed by Student $D$. Student $D$ said that she was happy learning English writing when her teaching using media of advertisement. Learning English writing by using advertisement as a media was very fun and she also was very interested in learning English writing. However, she found difficulties to write when she could not understand what has been explained by the teacher. She also said that lacked vocabulary has put in difficulty to write in English.

Next, Student E also confirmed that her English teacher used advertisement as a media in teaching. According to her, the media of advertisement has helped her effectiveness in studying English writing. It has improved her English writing ability since an advertisement comprises interesting words. Besides, she also said that sometimes she found difficulties in writing by using advertisement due to her limited understanding of vocabulary. Similarly, Student $F$ also experienced that advertisement was one of the effective media that the teacher used in teaching 
INTERNATIONAL JOURNAL OF ACADEMIC RESEARCH IN PROGRESSIVE EDUCATION AND DEVELOPMENT

Vol. 8, No. 2, 2019, E-ISSN: 2226-6348 @ 2019 HRMARS

English writing, as it has improved their vocabulary in writing. Most of the students, according to Student $\mathrm{F}$ were very enthusiast during the teaching and learning process.

Student $\mathrm{G}$ also confessed that learning by using advertisement was fun because and it has improved her vocabulary and have new information as written in the advertisement. She also could enhance her ability in writing. She admitted that writing was a difficult skill to learn without having enough vocabulary and understanding of the rules of writing. Student $H$ also found that using advertisement as media of teaching was interesting. It could motivate and improve her ability in English writing classes. She was an enthusiast to do the writing tasks given by the teacher.

Furthermore, Student I asserted that she liked learning English writing by using advertisement, it was fun and interesting. She stated that it was such good media that make the students practice English writing. She suggested that teachers should select appropriate and interesting media based on students' needs and interests. She added that writing was completely needed to learn as one of the English skills.

Finally, student J confessed that writing was difficult to be learned. It was due to the lack of his vocabulary and difficulty to express ideas. Expressing ideas in writing should be based on a topic sentence, otherwise writing result would not be coherence, she said. To improve writing skills, he suggested learning properly the rules of writing. He further said: "students have to practice writing and do writing assignments not only in the classroom but also at home". He totally agreed that that using advertisement in writing could help the students to improve their writing ability.

The above results of interviews both from teachers and students showed that using advertisement as a media in teaching writing was very effective. Students enjoyed benefits in their learning English writing by using advertisement. The use of advertisement as a media of teaching English writing was effective in teaching and learning process. It was very essential to enhance the students' ability in mastering English skills, especially in learning English writing. In addition, the students had a good response when teachers used advertisement in their teaching English writing classes and they were motivated to learn writing. Students' positive responses in the learning process were signed that they are motivated in learning English writing. Students felt happy and enthusiastic in learning English writing when the advertisement was used as the teaching media. Our findings are in harmony with previous studies such as Cohen (1994), Hapsari (2007), AlHammadi (2011), Cho (2011), Ismaili (2013), and Archer et al. (2014) who found that the use of media in teaching has improved student ability in English writing classes.

Comparing to the advertisement, using pictures as media is found by a teacher to be easier in teaching English writing to students. Using pictures as the media made students more interested to learn writing in English. Students were interested and motivated to learn English and it has improved their writing ability. However, most of the students faced difficulties in learning English writing by using advertisement and picture as the teaching media. These difficulties were due to the lack of students' vocabulary and structure of tenses

The effectiveness of advertisement in improving the writing skills of senior high school students was also confirmed by the students. Teachers who used advertisement as a media in teaching English writing made the teachings become more interesting, enthusiastic, joyful, and it has a good response from students. Students felt enthusiastic in writing classes and it has improved 
their vocabulary. However, the students also faced difficulties in writing due to the lack of vocabulary. These findings are in line with the studies by Liu (2010) and Keshta and Harb (2013) who found that lacking vocabulary among students have caused their difficulties in learning English writing skills.

Overall, our findings showed that media are very essential in the teaching and learning process. Therefore, the teachers have to use proper media in accordance with students' needs and interests in teaching to assist the students in improving their ability in English writing classes. Difficulties are a very common thing in learning; there are no learners who do not face difficulties. It is the teachers' responsibility to provide feedback for the students in learning, the difficulties faced by students could be easily resolved. Thus it is extremely important for English teachers to have good planning in their writing class (Kemp and Dayton, 1985), including in selecting proper media of teaching that most suitable to the needs of teaching subjects and students.

\section{Conclusion}

This study analyzed and described the effectiveness of using advertisement as a media of teaching writing English among Islamic state senior high school, Madrasah Aliyah Negeri (MAN) 1 in Aceh, Indonesia. Based on observations and interviews with the English teachers and students, the study found that almost all teachers in the school have used advertisements in their teaching English writing classes. The used of advertisements were found to be effective in teaching English writing. It has made the students happy and they were learning English writing enthusiastically. The advertisement has assisted the students to improve their ability in English writing as long as it is provided based on the students' needs and interests.

The students were effectively engaged and enthusiasm in doing English writing assignments assigned by the teachers when teachers using advertisement media in their English writing classes. However, most of the students faced difficulties in writing due to the lack of vocabulary. In essence, having enough vocabulary is completely essential to help the students to be easier in expressing their ideas in writing. Thus, it is the teachers' responsibility to motivate the students to master or memorize more vocabulary. In addition, teachers also should be responsible to monitor the students during English writing sessions and provide guidance to students if they had a problem in expressing their ideas in writing. The English teachers should encourage the students to practice more writing at home. To improve writing skills, students should be encouraged to do writing practices not only at school, but also outside of the school. During the process of teaching and learning English writing, it is suggested the teachers select and use teaching and learning media based on the students' needs and interests such as advertisements and pictures. Finally, teachers have also to provide feedback after they corrected the results of students' writing. It is one of the teachers' rules in the teaching and learning process, in addition to the use of media in improving English writing skills among the students of high school.

Further studies on the use of media in teaching English writing should cover more students from a different level of schools across the region in Indonesia to provide more comprehensive findings on the issue of interest. Additionally, comparing various types of media, including internet 
INTERNATIONAL JOURNAL OF ACADEMIC RESEARCH IN PROGRESSIVE EDUCATION AND

DEVELOPMENT

Vol. 8, No. 2, 2019, E-ISSN: 2226-6348 @ 2019 HRMARS

social media such as Facebook, Instagram, WhatApps, etc in improving writing skills of student could enrich the existing literature of the use of media in teaching and learning process.

\section{References}

Al-Hammadi, F. S. (2011). The effectiveness of using a multi-media software in developing some listening skills among Saudi secondary school students. Damascus University Journal, 27(3/4), 43-86

Archer, K., Savage, R., Sanghera-Sidhu, S., Wood, E., Gottardo, A., \& Chen, V. (2014). Examining the effectiveness of technology use in classrooms: A tertiary meta-analysis. Computers \& Education, 78, 140-149.

Arsyad, A. (1996). Media Pembelajaran. Jawa Barat: Raja Grafindo Persada.

Babayigit, S., \& Stainthorp, R. (2010). Component processes of early reading, spelling, and narrative writing skills in Turkish: A longitudinal study. Reading and Writing, 23(5), 539-568.

Bogdan, R. C., \& Biklen, R. K. (1998). Qualitative Research for Education: An Introduction to Theory and Methods (3rd ed.). Boston: Allyn and Bacon.

Cho, D. W. (2012). English-medium instruction in the university context of Korea: Tradeoff between teaching outcomes and media-initiated university ranking. The Journal of AsiaTEFL, 9(4), 135163.

Cohen, A. D. (1994), Assessing Language Ability in the Classroom. Boston: Heinie \& Heinie Publishers.

Hapsari, D. A. (2007). The Effectiveness of Using Different Teaching Media to Teach Vocabulary to Young Learners. Thesis. Malang: University of Muhammadiyah.

Harmer, J. (2004). How to Teach Writing, Longman: Pearson.

Hartig, H. (1962). Aims in Communication Courses. Improving College and University Teaching, 10(4), 187-189.

Heaton, J. B. (1995). Writing English Language Texts, New York: Longman.

Hyland, K., \& Hyland, F. (Eds.). (2019). Feedback in second language writing: Contexts and issues. Cambridge university press.

Ismaili, M. (2013). The effectiveness of using movies in the EFL classroom-a study conducted at South East European University. Academic Journal of Interdisciplinary Studies, 2(4), 121.

Jefkins, F. (2016). Advertising: Made Simple. Elsevier.

Kemp, J. E., \& Dayton, D. K. (1985). Planning and Producing Instructional Media. Harper \& Row.

Keraf, G. (2007). Argumentasi dan Narasi. Jakarta: Gramedia Pustaka.

Keshta, A. S., \& Harb, I. I. (2013). The effectiveness of a blended learning program on developing Palestinian tenth graders' English writing skills. Education Journal, 2(6), 208-221.

Kroll, B. (Ed.). (2003). Exploring the Dynamics of Second Language Writing. Cambridge University Press.

Lee, M., \& Johnson, C. (2013). Principles of Advertising: A Global Perspective. Routledge.

Liu, J. (2010). An Experimental Study on the Effectiveness of Multimedia in College English Teaching. English Language Teaching, 3(1), 191-194.

Miles, M. B., Huberman, A. M., Huberman, M. A., \& Huberman, M. (1994). Qualitative Data Analysis: An Expanded Sourcebook. USA: Sage. 
Munir, F. (2016). The effectiveness of teaching vocabulary by using cartoon film toward vocabulary mastery of EFL students. Journal of English Language Teaching and Linguistics, 1(1), 13-37.

Muslich, M. (2008). KTSP Pembelajaran Berbasis Kompetensi dan Kontekstual. Jakarta: PT. Bumi Aksara.

Peni, P. (2006). 30 Minutes Text Writing, Writing is Easy. Yogyakarta: Penerbit Andi.

Potrac, P., Jones, R. L., \& Nelson, L. (2014). Interpretivism. In Research methods in sports coaching (pp. 31-41). Routledge.

Siahaan, S. (2008). The English Paragraph. Yogyakarta: Graha IImu.

Suh, S., Kim, S. W., \& Kim, N. J. (2010). Effectiveness of MMORPG-based instruction in elementary English education in Korea. Journal of Computer Assisted Learning, 26(5), 370-378.

Suyanto, K. K. E. (2008). English for Young Learners. Jakarta: Bumi Aksara.

Thanh, N. C., \& Thanh, T. T. (2015). The interconnection between interpretivist paradigm and qualitative methods in education. American Journal of Educational Science, 1(2), 24-27.

Trier, J. (2006). Teaching with media and popular culture. Journal of Adolescent \& Adult Literacy, 49(5), 434-438.

Widyatma, R. (2009). Buku Pengantar Periklanan. Yogyakarta: Pustaka Book Publisher.

Xodabande, I. (2017). The effectiveness of social media network telegram in teaching English language pronunciation to Iranian EFL learners. Cogent Education, 4(1), 70-81. 